\title{
Study of Mud Crab Fattening in Earthen Pen Pond with Different Stocking Density
}

\section{Chakraborty BK* and Sarker S \\ Department of Fisheries, Dhaka, Bangladesh}

*Corresponding author: Binay Kumar Chakraborty, Department of Fisheries, Dhaka, Bangladesh, Tel: 008801715 470855; Email: bborty@gmail.com

\section{Research Article \\ Volume 2 Issue 5}

Received Date: September 10, 2018

Published Date: October 18, 2018

\section{Abstract}

The effect of stocking densities on the growth, survival and production of mud crab (Scylla spp.) was tested in a pen culture rearing system. The experiment was conducted for a rearing period of 90days in nine earthen pen culture ponds having an area of $1052 \mathrm{~m}^{2}$ with an average depth of $0.98 \pm 0.14 \mathrm{~m}$ each. Mud crabs stocked at the rate of $0.02,0.03$ and 0.04 million.ha-1 were designated as treatment $\mathrm{T}_{1}, \mathrm{~T}_{2}$ and $\mathrm{T}_{3}$. At stocking, all crabs were with an initial mean carapace length, carapace width and weight of individual was recorded in three treatments. Highest mean carapace length, carapace width and weight gain was documented $6.60 \pm 0.51 \mathrm{~cm}, 12.11 \pm 1.88 \mathrm{~cm}$ and $330.62 \pm 7.26 \mathrm{~g}$ in treatment $\mathrm{T}_{1}$ and lowest mean carapace length, carapace width and weight gain $6.18 \pm 0.36 \mathrm{~cm}, 10.02 \pm 2.28 \mathrm{~cm}$ and $252.52 \pm 3.44 \mathrm{~g}$ was in treatment $\mathrm{T}_{3}$. Survival of individual followed the same trends as weight gain. Mud crab in treatment $\mathrm{T}_{1}$ created significantly higher specific growth rate than treatment $T_{2}$ and $T_{3}$. Feed conversion ratio was significantly lowest in treatment $\mathrm{T}_{1}$ followed by treatment $\mathrm{T}_{2}$ and $\mathrm{T}_{3}$ in that order. In despite of this, consistently higher net benefits were found from treatment $\mathrm{T}_{1}$ than from treatment $\mathrm{T}_{3}$ and $\mathrm{T}_{2}$ and also significant $(P<0.05)$. Overall, highest growth, survival, production and net benefit of mud crab were recorded at a stocking density of 0.02 million individual.ha ${ }^{-1}$. Therefore, of the three stocking densities, 0.020 million individual. ha-1 appears to be most suitable stocking density for rearing of mud crab in earthen pen in pond culture system.

Keywords: Mud crab; Fattening; Stocking density; Carapace width; Growth; Survival; Benefits

\section{Introduction}

Various studies of mud crab aquaculture have been undertaken in the Indo-Pacific region [1]. In the Philippine, pond culture trial on the culture of mud crab to determine its optimum stocking density [2] and in polyculture with milkfish [3] has been practiced to yield economically viable production $[4,5]$. The most commonly cultured crab species is Scylla spp. due to its preference to estuarine habitats, less aggressive behaviour and higher value [6]. In Taiwan, Scylla spp. has been reared in both polyculture (together with shrimps, milkfish and rice) and monoculture ponds [6,7]. In Philippines, the species has been cultured in ponds [5,8-10] as well as in pens [2]. In East Malaysia, pen culture has been practiced where the mud crabs are allowed to grow in their natural habitat in enclosures in mangroves [11]. Pen culture is to be originated in the inland sea area of Japan in the early 1920's [12] and adopted by the People's Republic of China in the 1950's for rearing of carps in freshwater lakes [13]. 


\section{International Journal of Oceanography \& Aquaculture}

From there, it has been successfully extended for the culture of tilapia and carp [14]. At present, it is commercially practiced only in the Bangladesh, Philippines, Indonesia and China [13].

Mud crab culture practice in Bangladesh is totally dependent on wild resource. Once the coastal area of Bangladesh was abundance of mud crabs. Due to over exploitation and various ecological changes in the mangrove area, the population of mud crab is decreasing day by day. The mangrove area is to be great stress and its existence is under danger because of changing aquatic ecosystems and habitat degradation. Indiscriminate destructive capturing crab practice and lower salinity have caused to destroy the aquatic biodiversity of coastal area. Mud crabs of the genus Scylla are importance as a source of delicious food and income throughout much of the tropical Indo-Pacific and as a consequence have been reduced, in both abundance and size, throughout much of their range [15-17]. The mud crabs of the coastal area were subjected to over fishing resulting in gradual decline in crab population [18]. To overcome the basic requirement of mud crab fry in the aquaculture field, crab hatchery should be established in the coastal region of Bangladesh. Until to establish crab hatchery, eco-friendly capture system of mud crab should be developed to continue gonad development of crab in pen and case culture [18].

The present study was under taken to evaluate the growth, survival and production of mud crabs with different stocking densities and to demonstrate the economic viability and profitability of different treatments under controlled pen culture management system.

\section{Materials and Methods}

\section{Study Area and Experimental Design}

An experiment of pen culture of mud was designed in net pens at the ponds of Kaligong, Satkhira; Morolgong, Bhagherhat and Sadar upazilla, Cox's Bazar; Bangladesh Figure 1.

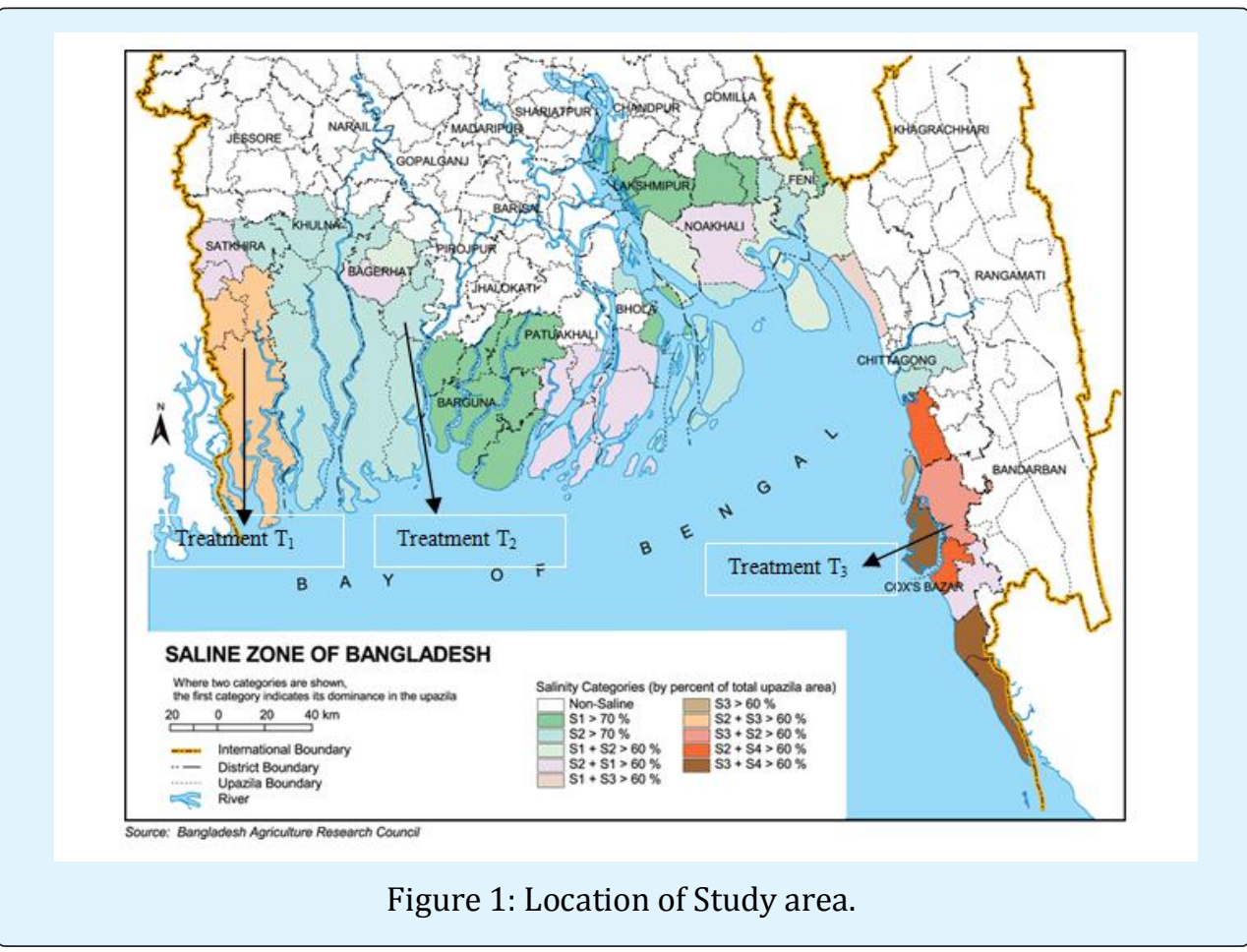

The study was conducted for a period of 90 days from October to December 2017 in nine pens of earthen pond. The area of pen was $1052 \mathrm{~m}^{2}$ in each with an average depth of $0.98 \pm 0.14 \mathrm{~m}$ with a low turbidity, absence of pollutants, firm bottom condition and protection from high winds. The pen of ponds was encircled with bamboo slits made fence having similar rectangular size and depth. The bamboo slits was pushed into the mud up to $50 \mathrm{~cm}$ depth to prevent escape burrowing of crabs. The pen was fenced with monofilament nets of mesh size 5 $\mathrm{mm}$. The net was fixed to the bottom and supported with wooden pole. The height of the enclosures was 


\section{International Journal of Oceanography \& Aquaculture}

maintained at $1.2 \mathrm{~m}$ during unfavourable climatic conditions. Saline water exchange in these enclosed water bodies was connected by tidal fluctuation. Three treatments with three replicates each were designed and differing in stocking densities were $2.0 \mathrm{~m} 2$ (treatment T1), $3.0 \mathrm{~m} 2$ (treatment T2) and $4.0 \mathrm{~m} 2$ (treatment T3).

\section{Pond Preparation, Stocking and Fertilization}

The dyke and gate of the ponds were repaired and the ponds were exposed to full sunlight and had a well designed system of inlet and outlet. After drying, quicklime $\left(\mathrm{CaCO}_{3}, 250 \mathrm{~kg} \cdot \mathrm{ha}^{-1}\right)$ was spread over the pond bottom. All the ponds were filled with saline water Figures 2a-2c. Five days subsequent to liming, the ponds were fertilized with muster oilcake at the rate of $124.0 \mathrm{~kg} . \mathrm{ha}^{-1}$. The experimental ponds were stocked with an initial weight of $190.50 \pm 3.05 \mathrm{gm}$ old mud crab.

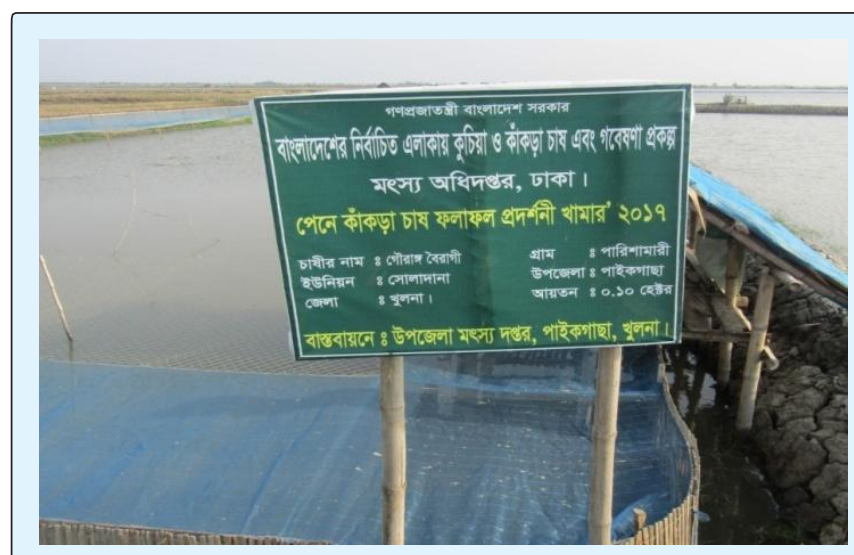

Figure 2a: Mud crab fattening in pen aquaculture system at Paikgacha.

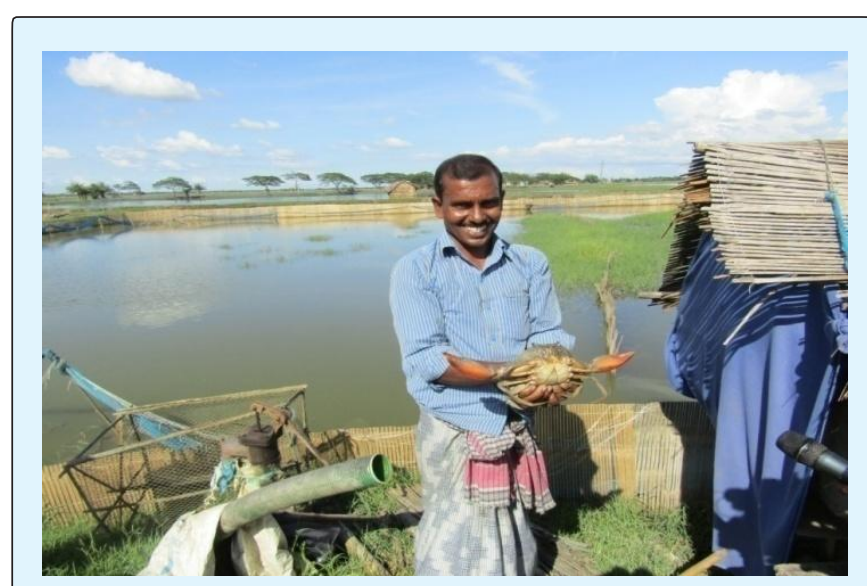

Figure 2b: Mud crab fattening in pen aquaculture system at Kaligong.

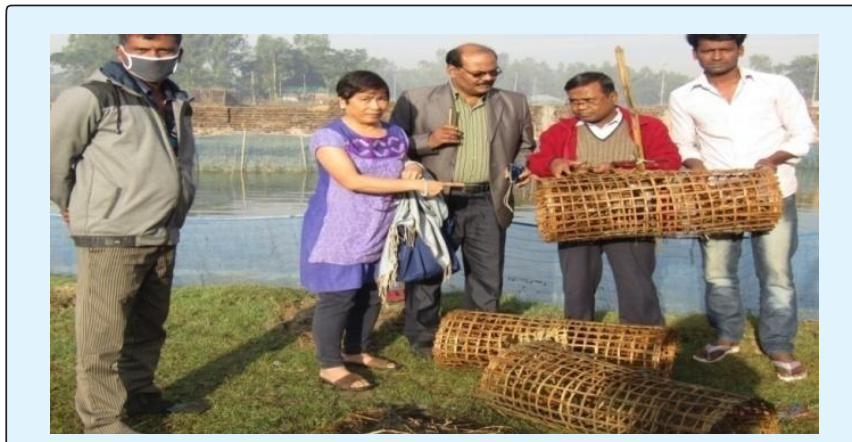

Figure 2c: Mud crab fattening in pen aquaculture system at Sadar, Cox'sBazar.

\section{Supplementary Feeding}

In order to meet dietary demand, trash fish including tilapia as feed was supplied at the rate of $(2-5) \%$ of their total biomass twice daily commencing from the first day of stocking. The rate of feeding was maintained $5 \%$ depending on carapace width $<7-8 \mathrm{~cm}$ and $4 \%$ depending on carapace width $<8-9 \mathrm{~cm}, 3 \%$ depending on carapace width $<9-10 \mathrm{~cm}$ and $2 \%$ depending on carapace width $<10-11 \mathrm{~cm}$. Daily ration was adjusted by estimating the standing crop once in each fortnightly by random sampling of the stock.

\section{Water Quality Parameters}

Physico-chemical parameters of pond water were monitored fortnightly between 9.00 and $10.00 \mathrm{~h}$. A caliper was used to measure the carapace width. Water temperature was recorded using a Celsius thermometer and salinity of water was measured by Refactometer. Dissolved oxygen and $\mathrm{pH}$ were measured directly using a digital electronic oxygen meter (YSI, Model 58, USA) and an electronic pH meter (Jenway, Model 3020, UK).

\section{Development of Habitat}

To control cannibalism of crab a well established shelter was developed. Plastic pipe and grass culture acted as crab shelters, minimizing mortality and loss of stock due to cannibalism [19]. Point out that the application of crab shelters increased survival by minimizing antagonistic encounters.

\section{Estimation of Growth, Survival, Production and Feed Utilization}

Total yield $(\mathrm{kg})$ and number of crabs harvested from each pen of the pond were recorded. Ten percent of the population from each pond was randomly sampled and 


\section{International Journal of Oceanography \& Aquaculture}

individually weighed with the help of a portable sensitive balance (Model HL 400 EX) and measured for carapace length (CL) and carapace width (CW) with a measuring scale until they attained marketing size. The growth, apparent feed conversion ratio (FCR), survival, average daily gain (ADG) and specific growth rate (SGR) was estimated. SGR and FCR were calculated according to Brown [21]; Castell \& Tiews [22] and Gangadhara, et al. respectively [23]. After 90 days, the crabs were harvested by trap and draining or drying the ponds. The number of species were counted and weighed. Survival (\%) and production (wt.ha ${ }^{-1}$ ) of crabs were then calculated and compared among the treatments.

\section{Economic Analysis}

The cost analysis was in terms of hectare to maintain a standard unit. Cost-return and partial budgeting analyses were done to compare the viability and profitability of the various treatments used [24].

\section{Analysis of Experimental Data}

The data were analyzed through one way analysis of variance (ANOVA) using MSTAT followed by Duncan's New Multiple Range test to find out whether any significant difference existed among treatment means $[25,26,27]$.

\section{Results}

\section{Water Quality Parameters}

Pond water quality did not vary much among the three treatments. Values recorded for the duration of the experiment were: temperature, 18.30 to $29.5^{\circ} \mathrm{C}$; salinity, 8.6 to $18.4 \mathrm{ppt}$; DO. 4.8 to $6.2 \mathrm{ppm}$; $\mathrm{pH}, 7.7$ to 8.8 . The values were within the ranges reported by Trino, et al. [10] and were generally within the acceptable ranges of mud crab culture [28].

\section{Growth, Feed Utilization and Production of Fish}

The growth and production of crabs in term of gain in weight under three treatments were investigated and monitored fortnightly. The results obtained are presented in Table 1, Figures 3-5 which indicated that the growth in terms of weight showed much variation in different treatment and continued till final harvesting. No formulated feed was used in this experiment. During the study, final weight of crab was recorded to be $330.62 \pm 7.26,291.22 \pm 4.01$ and $252.52 \pm 3.44 \mathrm{~g}$ in treatment $\mathrm{T}_{1}, \mathrm{~T}_{2}$ and $\mathrm{T}_{3}$, respectively. The increase in weight mud crab was the highest in $T_{1}$ followed by $T_{2}$ and $T_{3}$, respectively. The initial carapace length, carapace width and weight $(4.04 \pm 0.43 \mathrm{~cm}, 7.12 \pm 0.34 \mathrm{~cm}$ and $190.50 \pm 3.05$ g) of crab stocked in all the ponds were the same. The crab in treatment $\mathrm{T}_{1}$ showed the highest gain in carapace length, carapace width and weight $(6.60 \pm 0.51 \mathrm{~cm}$, $12.11 \pm 1.88 \mathrm{~cm}$ and $330.62 \pm 7.26 \mathrm{~g}$ ) compared to the treatments $T_{2}$ and $T_{3}$, where stocking density of mud crabs was 0.020 million. ha $^{-1}$. However, the mean final weights of mud crab in different treatments were significantly different $(P<0.05)$. SGR in treatment $\mathrm{T}_{1}$ was significantly higher than in $\mathrm{T}_{2}$ and $\mathrm{T}_{3}(P<0.05)$. Food conversion ratio was significantly lower in $\mathrm{T}_{1}$ than $\mathrm{T}_{2}$ and $\mathrm{T}_{3}$. Therefore, best SGR $(1.39 \pm 0.04)$ and FCR $(2.05 \pm 0.02)$ were recorded in treatment $\mathrm{T}_{1}$ where lowest number of juvenile of crab was reared. The highest survival rate

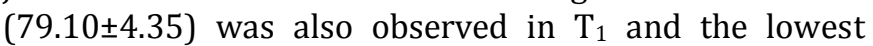
$(51.52 \pm 1.67)$ in $\mathrm{T}_{3}$. There was a significant variation $(P<0.05)$ in the survival rate of crabs among different treatments. The net production of crab was (5231.00 $\pm 2.28 \mathrm{~kg}),(5280.00 \pm 5.75 \mathrm{~kg})$ and $(5204.00 \pm 6.85 \mathrm{~kg}) \mathrm{ha}^{-}$ ${ }^{1}$.days ${ }^{-90}$ in treatment $T_{1}, T_{2}$ and $T_{3}$ respectively. Total production of mud crab was recorded to be more or less in three treatments. On the other hand, highest number of crabs was stocked in treatments $\mathrm{T}_{3}$ where lowest survival rate was recorded. But no significant $(P<0.05)$ different was recorded in case total production in three treatments Table 1.

\begin{tabular}{|c|c|c|c|}
\hline \multirow{2}{*}{ Parameters } & \multicolumn{3}{|c|}{ Treatments } \\
\cline { 2 - 4 } & $\mathbf{T}_{\mathbf{1}}$ & $\mathbf{T}_{\mathbf{2}}$ & $\mathbf{T}_{\mathbf{3}}$ \\
\hline Initial carapace length $(\mathrm{cm})$ & $4.04 \pm 0.43$ & $4.04 \pm 0.43$ & $4.04 \pm 0.43$ \\
& $(3.50-4.52)$ & $(3.50-4.52)$ & $(3.50-4.52)$ \\
\hline Final carapace length (cm) & $6.60 \pm 0.51$ & $6.32 \pm 0.32$ & $6.01 \pm 0.36$ \\
& $(6.20-7.12)$ & $(6.11-6.58)$ & $7.98-6.14)$ \\
\hline Initial carapace width (cm) & $7.12 \pm 0.34$ & $7.12 \pm 0.34$ & $(7.00-8.11)$ \\
& $(7.00-.11)$ & $(7.00-8.11)$ & $10.02 \pm 2.28$ \\
& $12.11 \pm 1.88$ & $11.22 \pm 2.10$ & $(9.77-11.22)$ \\
\hline
\end{tabular}




\section{International Journal of Oceanography \& Aquaculture}

\begin{tabular}{|c|c|c|c|}
\hline Initial body weight (g) & $\begin{array}{c}190.50 \pm 3.05 \\
(181.50-210.60)\end{array}$ & $\begin{array}{c}190.50 \pm 3.05 \\
(181.50-210.60)\end{array}$ & $\begin{array}{c}190.50 \pm 3.05 \\
(181.50-210.60)\end{array}$ \\
\hline Final body weight (g) & $330.62 \pm 7.26^{\mathrm{a}}$ & $291.22 \pm 4.01^{\mathrm{b}}$ & $252.52 \pm 3.44^{\mathrm{c}}$ \\
& $(280.18-360.64)$ & $(240.14-311.18)$ & $(218.02-282.22)$ \\
\hline Net weight gain (g) & $140.12 \pm 3.01^{\mathrm{a}}$ & $100.72 \pm 3.228^{\mathrm{b}}$ & $52.02 \pm 3.34^{\mathrm{b}}$ \\
& $(132.10-162.22)$ & $(91.10-112.32)$ & $(46.01-61.82)$ \\
\hline Average daily gain(g) & $1.56 \pm 0.03^{\mathrm{a}}$ & $1.12 \pm 0.04^{\mathrm{b}}$ & $0.58 \pm 0.05^{\mathrm{c}}$ \\
& $(1.50-1.64)$ & $(1.01-1.32)$ & $(0.50-0.65)$ \\
\hline Specific growth rate & $0.61 \pm 0.01^{\mathrm{a}}$ & $0.47 \pm 0.01^{\mathrm{b}}$ & $0.31 \pm 0.01^{\mathrm{c}}$ \\
& $(0.55-0.62)$ & $(0.45-0.48)$ & $(0.30-0.32)$ \\
\hline Survival rate (\%) & $79.10 \pm 4.35^{\mathrm{a}}$ & $60.44 \pm 2.67^{\mathrm{b}}$ & $51.52 \pm 1.67^{\mathrm{c}}$ \\
& $(75.20-83.80)$ & $(58.80-63.52)$ & $(50.12-53.36)$ \\
\hline FCR & $2.05 \pm 0.02^{\mathrm{a}}$ & $2.34 \pm 0.04^{\mathrm{b}}$ & $2.62 \pm 0.05^{\mathrm{c}}$ \\
& $(1.90-2.20)$ & $(2.05-2.44)$ & $(2.50-2.80)$ \\
\hline Production (kg.ha-1) & $5231.00 \pm 2.28^{\mathrm{a}}$ & $5280.00 \pm 5.75^{\mathrm{b}}$ & $5204.00 \pm 6.85^{\mathrm{c}}$ \\
& $(5228.02-5232.35)$ & $(5269.22-5290.66)$ & $(5200.10-5207.8)$ \\
\hline
\end{tabular}

.610 .470 .31

Figure in the same row having the same superscript are not significantly different $(\mathrm{P}>0.05)$. Values in the parenthesis indicate the range.

\# Total crop of crabs harvested after 90 days.

Average daily gain $(\mathrm{g})=$ (mean final weight - mean initial weight) / time interval (days).

Specific growth rate $(\mathrm{SGR})=$ Ln mean final weight - Ln mean initial weight)/time interval (days) $\times 100$.

FCR $($ Feed conversion ratio $)=$ Total diet fed $(\mathrm{kg}) /$ total wet weight gain $(\mathrm{kg})$.

Table 1: Survival, feed conversion ratio (FCR), Growth performance and production of Scylla spp. after 90 days of rearing; mean \pm S.D. with ranges in parentheses.

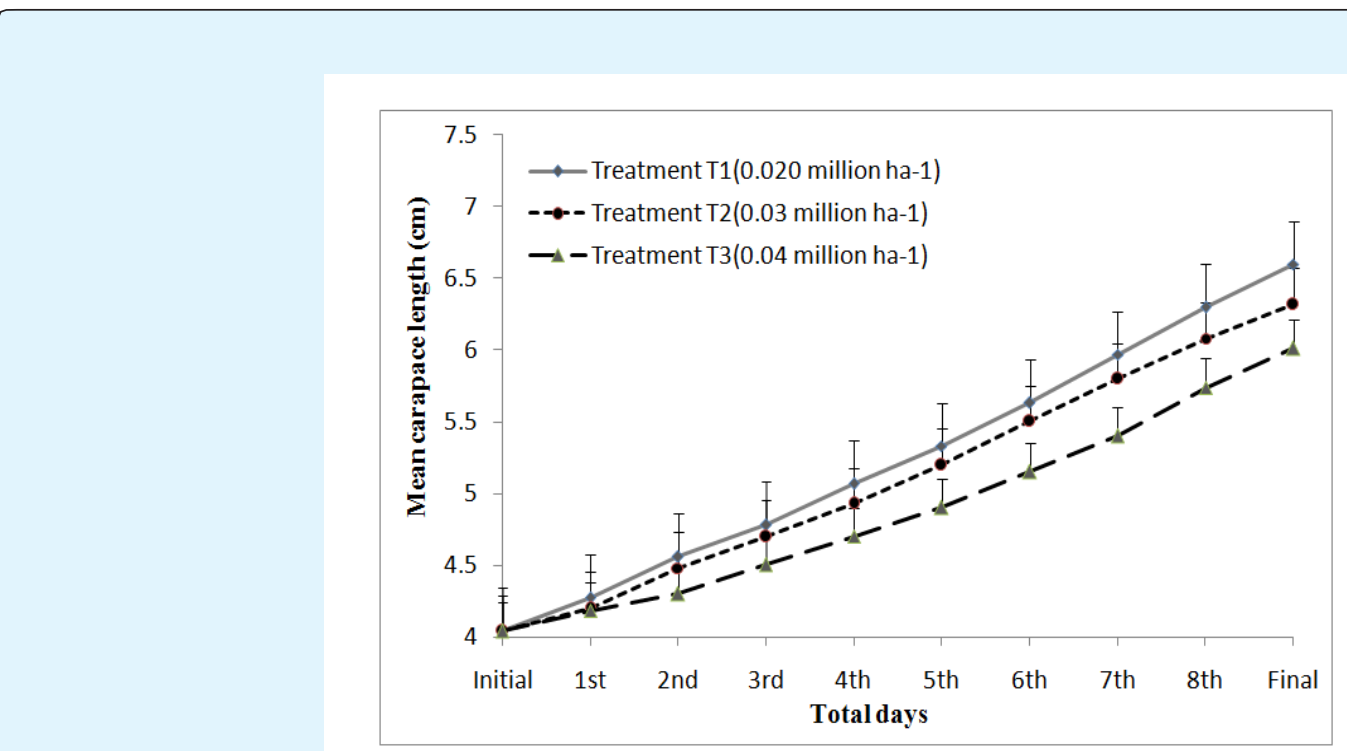

Figure 3: About 10 day's interval means carapace length $(\mathrm{cm})$ of mud crab genera Scylla under different density. 


\section{International Journal of Oceanography \& Aquaculture}

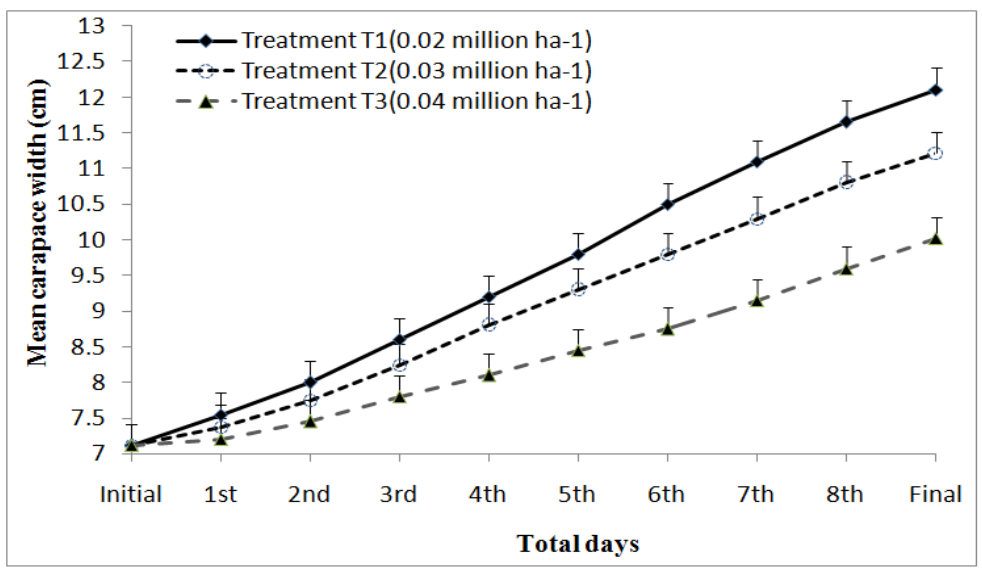

Figure 4: About 10 day's interval means carapace width $(\mathrm{cm})$ of mud crab genera Scylla under different density.

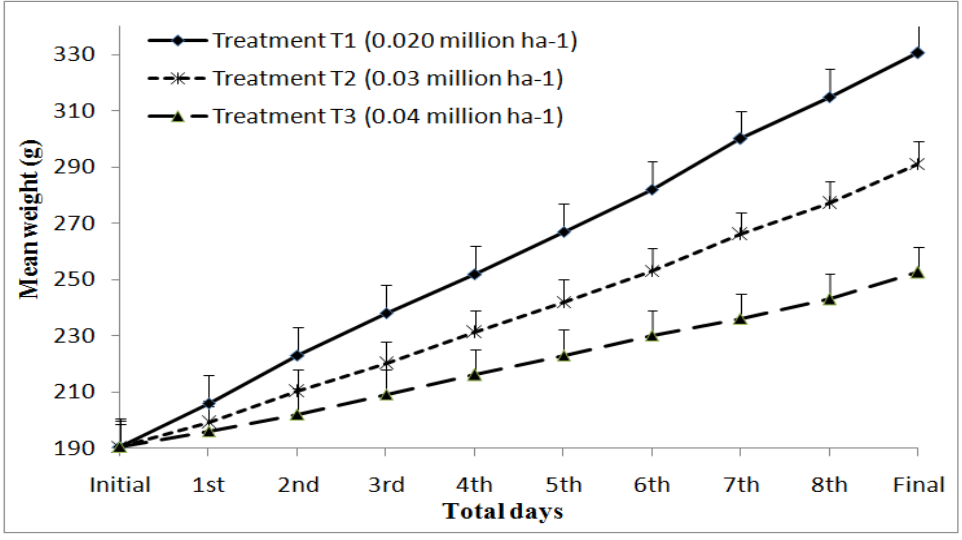

Figure 5: About 10 day's interval means weight gain (g) of mud crab genera Scylla under different density.

In Table 2, it is evidence that about 45.02, 50.55 and $52.43 \%$ male was recorded and total production of male was $2606.00 \pm 2.28,2789.00 \pm 4.88$ and $2936.00 \pm 3.99 \mathrm{~kg}$ in treatment $\mathrm{T}_{1} \mathrm{~T}_{2}$ and $\mathrm{T}_{3}$, respectively. On the other hand, female percentage was $54.98,49.45$ and $47.57 \%$ and total production of female was recorded at $2625.00 \pm 2.58$, $2491.0 \pm 5.63$ and $2268.00 \pm 3.58 \mathrm{~kg}$ in treatment $\mathrm{T}_{1}, \mathrm{~T}_{2}$ and $\mathrm{T}_{3}$.

\begin{tabular}{|c|c|c|c|c|c|c|c|c|c|}
\hline \multirow{2}{*}{$\begin{array}{c}\text { Species } \\
\text { Name }\end{array}$} & \multicolumn{3}{|c|}{ Treatment T } & \multicolumn{3}{c|}{ Treatment T } & \multicolumn{3}{c|}{ Treatment T $_{\mathbf{3}}$} \\
\cline { 2 - 10 } & Number & Percentage & Production & Number & Percentage & Production & Number & Percentage & Production \\
\cline { 2 - 10 } & $\mathbf{( \# )}$ & $\mathbf{( \% )}$ & $\mathbf{( k g )}$ & $\mathbf{( \# )}$ & $\mathbf{( \% )}$ & $\mathbf{( k g )}$ & $\mathbf{( \# )}$ & $\mathbf{( \% )}$ & $\mathbf{( k g )}$ \\
\hline Male & 7122 & 45.02 & $2606.00 \pm 2.28$ & 9166 & 50.55 & $2789 \pm 4.88$ & 10804 & 52.43 & $2936 \pm 3.99$ \\
\hline Female & 8698 & 54.98 & $2625 \pm 2.58$ & 8966 & 49.45 & $2491 \pm 5.63$ & 9804 & 47.57 & $2268 \pm 3.58$ \\
\hline Total & 15820 & 100 & $5231.00 \pm 2.28$ & 18132 & 100 & $5280.00 \pm 5.7$ & 20608 & 100 & $5204.00 \pm 6.85$ \\
\hline
\end{tabular}

Table 2: Identification of mud crab species, number, percentage and production of genera Scylla in three treatments Scylla serrata Scylla olivacea. 
Total cost production in treatment $\mathrm{T}_{1}, \mathrm{~T}_{2}$ and $\mathrm{T}_{3}$ was recorded BDTk. 2799626, 2727932 and 4633931 respectively. On the other hand, cost of production in treatment $\mathrm{T}_{3}$ was consistently higher than those treatments $T_{2}$ and $T_{1}$ (Table 3 ). Highest net return (in term of Bangladeshi Tk.ha ${ }^{-1}$ and one US $\$=$ Bangladeshi TK. 84) was obtained in treatment $\mathrm{T}_{1}$ (2954474) followed by $\mathrm{T}_{2}(1132672)$ and $\mathrm{T}_{3}(49669)$ in that order.

\begin{tabular}{|c|c|c|c|c|}
\hline \multirow[b]{2}{*}{ Item } & \multicolumn{3}{|c|}{ Amount TK•ha-1•day ${ }^{-90}$} & \multirow[b]{2}{*}{ Remarks } \\
\hline & $\begin{array}{l}\text { Treatment } T_{1} \\
\text { (Tk) }\end{array}$ & $\begin{array}{c}\text { Treatment } T_{2} \\
\text { (Tk) }\end{array}$ & $\begin{array}{l}\text { Treatment } T_{3} \\
\text { (Tk) }\end{array}$ & \\
\hline Total return (TR) & 5754100 & 4752000 & 4683600 & $\begin{array}{l}\text { Price is related with different grade (size } \\
\text { and weight) }\end{array}$ \\
\hline \multicolumn{5}{|c|}{ a. Variable cost: } \\
\hline Price of crab & 1524000 & 2286000 & 3048000 & Tk. $400 . \mathrm{kg}^{-1}$ \\
\hline Feed (Trash fish) & 927600 & 990440 & 1070132 & Tk. $60 . \mathrm{kg}^{-1}$ \\
\hline Fertilizer, lime etc. & 10015 & 10015 & 10015 & \\
\hline Human labour cost & 40500 & 40500 & 40500 & 01 labor Tk.400.day ${ }^{-1}$ \\
\hline Chemicals & 5000 & 6380 & 6018 & \\
\hline \begin{tabular}{|c|} 
Miscellaneous \\
\end{tabular} & 20000 & 20000 & 20000 & With netting \\
\hline Total Variable cost (TVC) & 2527115 & 3353335 & 4194665 & \\
\hline \multicolumn{5}{|c|}{ b. Fixed cost : } \\
\hline Pond rental value & 19800 & 19800 & 19800 & Tk. 200.00 dec. $^{-1}$ according to local rate \\
\hline Interest of operating capital & 252711 & 246193 & 419466 & $\begin{array}{c}10 \% \text { interest according to } \mathrm{BKB}, \\
\text { Bangladesh }\end{array}$ \\
\hline Total fixed cost (TFC) & 272511 & 265993 & 439266 & \\
\hline Total cost $(\mathrm{TC}=\mathrm{TVC}+\mathrm{TFC})$ & 2799626 & 3619328 & 4633931 & \\
\hline \begin{tabular}{|c|} 
Gross margin (GM= TR- \\
TVC)
\end{tabular} & 3226985 & 1398665 & 488935 & \\
\hline Net return (TR-TC) & 2954474 & 1132672 & 49669 & \\
\hline
\end{tabular}

a1 US\$ = BDTk. 84.00

$\mathrm{BKB}=$ Bangladesh Krishi Bank

Figures with different superscripts in the same row varied significantly $(P<0.05)$. Figures in the parenthesis indicate range. bSale price Tk.1100.00 kg-1 $\left(\mathrm{T}_{1}\right), \mathrm{Tk} .1000 .00 \mathrm{~kg}-1\left(\mathrm{~T}_{2}\right)$ and Tk.900.00 kg-1 $\left(\mathrm{T}_{3}\right)$.

Table 3: Cost and benefits from the mud crab of genera Scylla in 1-ha earthen pen of ponds for a period of 90 days.

\section{Discussion}

The stocking densities of the crab were 0.02 million.ha-1 (treatment $\mathrm{T}_{1}$ ), 0.03 million.ha-1 (treatment $\mathrm{T}_{2}$ ) and 0.04 million.ha- ${ }^{-1}$ (treatment $\mathrm{T}_{3}$ ), respectively; which were significantly compared to other trial cultures conducted in Taiwan by Chen, 1990. Cannibalism was found in different treatments which are agreed by $[2,29,30]$. They found common in mud crab culture when high stocking densities and mixed sex culture are practiced.

Survival of mud crab for the present study was recorded at the range from 50.12 to $83.80 \%$ which is agreed by Trino, et al. $[10,31]$. He reported that the loss of crabs grown in ponds can be relatively high, from $40 \%$ to $60 \%$, if the stocking rates are high. The three stocking densities $\left(0.02,0.03\right.$ and 0.04 million ha $\left.{ }^{-1}\right)$ for mud crab used in the study were within the range recommended by Trino, et al. [10]. In this study, the survival was comparatively lower due to higher stocking density and highly cannibalisom of mud crab during molting and postmolt crabs [20,19,32]. The pen in three treatments had a sandy and muddy bottom with pieces of plastic pipe and grass. In this study, plastic pipe and grass culture acted as crab shelters, minimizing mortality and loss of stock due to cannibalism [19]. Fielder, et al. point out that the application of crab shelters increased survival by minimizing antagonistic encounters [20]. 


\section{International Journal of Oceanography \& Aquaculture}

Growth in terms of length, weight, weight gain and SGR of crab was significantly higher in $\mathrm{T}_{1}$ where the stocking density was low compared to those of $\mathrm{T}_{2}$ and $\mathrm{T}_{3}$ although same food was supplied in all the treatments at an equal ratio. The low growth rate crab in treatment $T_{2}$ and $\mathrm{T}_{3}$ appeared to be related with higher densities and increased competition for food and space and an inverse relationship with in the stocking density provided that space-limiting effects operate on the population $[11,33,34]$. In this study, at higher stocking densities, presence of abundant food substances could produce a comparative interaction among the population causing a stressful situation [35].

This experiment has shown that the crabs were able to grow in the pen, as indicated by the increase in SGR values in three treatments. Similar growth rates is recorded by Bensam [36] who found increase in weight ranging from 2.3 times to 3.5 times in a period of 90 days culture.

However the lower FCR value in the present study indicates better food utilization efficiency, despite the values increased with increasing stocking densities. Significantly higher survival was noted in treatment $\mathrm{T}_{1}$, where, the stocking density was lower than $\mathrm{T}_{2}$ and $\mathrm{T}_{3}$. The reason for reduced survival rate in these treatments was due to higher stocking density of population as well as competition for food and space in the experimental ponds [36].

In the present study, a significant lower number of populations were stocked in treatment $\mathrm{T}_{1}$ with 0.02 million.ha ${ }^{-1}$ than those of from the treatment $\mathrm{T}_{2}$ and $\mathrm{T}_{3}$ stocked with 0.03 and 0.04 million.ha- ${ }^{-1}$, respectively. Despite this, consistently higher net benefits were obtained from ponds stocked with 0.02 million.ha $^{-1}$ than those from the treatment $T_{2}$ and $T_{3}$. The higher grade of mud crab was produced in treatment $\mathrm{T}_{1}$ with 0.02 million.ha- ${ }^{-1}$, substantially increased the net benefit compared to smaller grade of crab that produced in other treatments with higher stocking densities $[18,36]$. Overall, highest growth, survival and benefits of pen culture were recorded at a density of 0.0 .02 million.ha $^{-1}$.

The mangrove crab is omnivorous and feeds on raw crushed fish, crustaceans, bivalves, molluscs, penaeids and detrital matter. The application of trash fish as feed, the presence of naturally occurring food and muddy nature favoured the growth of mud crab [37]. Growth of crab to a greater extent depended on the quality of food available. No formulated feed was supplied in this study.
Because price of formulated feed is more or less double of price of trash fish. In the present experiment, the amount of trash fish given in different treatments was based on the weight of crab stocked and amount of feed provided per individual was kept at the same level. Hence, the observed low growth at higher stocking densities could be due to availability of cannibalism character and some variations in environmental parameters [8]. The results in the present experiment are very similar to those of Escritor, Samonto \& Agbayani, Mwaluma and Bensam and Chakraborty $[5,18,30,36,37]$.

Partial budget analysis showed an increase in revenues and decreases in working capital when lower stocking density and monosex female crabs are used for culture. This resulted in a substantial net benefit can be earned from treatment $\mathrm{T}_{1}[10]$. Prices of mud crab in the Bangladesh are not stable and fluctuate depending on season and sex. The price is relatively higher during the months of November to March. The trend in market price indicates that female crabs are offered a much higher price, thus, widening the price margin between female and male [38].

Finally, it can be concluded that the survival, growth, production of $S$. serrata were inversely related to the stocking densities of crabs. Stocking density of 0.02 million.ha ${ }^{-1}$ (02 individual. $\mathrm{m}^{-1}$ ) may be advisable for rearing of mud crab for 90 days culture period. The present study was undertaken to evaluate the growth, survival and production of crabs and to demonstrate the economic viability and profitability of the different densities $[39,40]$.

\section{Acknowledgement}

The authors wish to thank Project Director, Culture of cuchia and crab in the selected area of Bangladesh and research Project, Department of Fisheries, Bangladesh who helps for successfully conducting the experiments with financial support.

\section{References}

1. Angell CA (1992) Summary of the proceedings of the Seminar on the mud crab. The Mud Crab A Report of the Seminar on Mud Crab Culture and Trade, Bay of Bengal Programme, Madras, India, pp: 1-4.

2. Baliao DD, Rodriguez EM, Gerochi DD (1981) Culture of mud crab Scylla serrata (Forskal) at different 


\section{International Journal of Oceanography \& Aquaculture}

stocking densities in brackish water ponds. SEAFDEC/AQDQ 5(1): 10-14.

3. Lijauco MM, Prospero OQ, Rodriguez EM (1980). Polyculture of milkfish (Chanos chanos) and mud crab (Scylla serrata) at two stocking densities. SEAFDEC/AQDIR 4(40): 19-23.

4. Agbayani RF, Baliao DD, Samonte GPB, Tumaliuan RE, Caturao RD (1990) Economic feasibility analysis of the monoculture of mud crab (Scylla serrata) Forsskal. Aquaculture 91: 223-231.

5. Samonto GPB, Agbayani RF (1992) Pond Culture of mud crab (Scylla serrata). An economic analysis. SEAFDEC Asian Aquaculture 14(4): 3-5.

6. Cowan L (1984) Crab farming in Japan, Taiwan and the Philippines/Lynda Cowan. Trove: 43-61.

7. Chen TP (1976) Aquaculture practices in Taiwan. CABI: 123-128.

8. Catanaoan (1972) Crab farming in the Philippines. World Farming 14: 9.

9. Baguilat $T$ (1979). The fish pen industry (of the Philippines): An Overview. In: Proceedings of the SEAFDEC/IDRC International Workshop on Pen and Cage Culture of Fish, Philippines: 134-138.

10. Trino AT, Millamena OM, Keenan C (1999) Commercial evaluation of monosex pond culture of the mud crab Scylla species at three stocking densities in the Philippines. Aquaculture 174: 109118.

11. Chang WW (1997) Pen culture of mud crabs in the mangrove ecosystems in Sarawak (East Malaysia). Aqua Asia 2(4): 3-5.

12. Alferez VN (1977) Engineering aspects and problems in the design and construction of fish pens and fish cages in Laguna Lake, Philippines. In: Joint SCSP/SEAFDEC Workshop on aquaculture engineering (with emphasis on small-scale aquaculture projects), SCS/GEN/77/15, 2: 373-388.

13. Beveridge MCM (1984) Cage and pen fish farming. Carrying capacity models and environmental impact. FAO Fish Tech (255): 131.

14. Rabanal HR (1988b) History of aquaculture. ASEAN/UNDP/FAO Regional Small-Scale Coastal
Fisheries Development Project Manila, Philippines, 1: 13.

15. Brown IW (1993) Nearshore marine resources of the South Pacific: Information for fisheries management and development. In: Wright A, Hill L, Forum Fisheries, pp: 611-642.

16. Naylor R, Drew M (1998) Valuing mangrove resources in Kosrae, Micronesia. Environ Dev Econ 3(4): 471-490.

17. Marichamy R, Rajapackiam S (2001) The aquaculture of Scylla species in India. Asian Fish Sci 14(2): 231238.

18. Chakraborty BK (2018) Effect of Stocking Density on Survival, Growth and Production of Mud Crab Juvenile by Pen Culture System of Bangladesh. Int J Oceanogr Aquac 2(4): 1-11.

19. Chen LC (1990) Mud crab culture. In: Aquaculture in Taiwan. Fishing News Books, London. pp: 142-149.

20. Fielder DS, Mann DL, Heasman MP (1988) Development of intensive pond farming techniques for the mud crab Scylla serrata (Forskal) in Northern Australia. FIRTA Project Report 86/9.

21. Brown ME (1957) Experimental studies on growth. In: The physiology of fishes, Academic Press, New York, 1: 361-400.

22. Castell JD, Tiews K (1980) Report of the EIFAC, IUNS and ICES Working Group on the Standardization of Methodology in Fish Nutrition Research. (Hamburg, Federal Republic of Germany, 21-23 March 1979). EIFAC Technical Paper (36).

23. Gangadhara B, Nandeesha MC, Varghese TJ, Keshavanath P (1997) Effect of varying protein and lipid levels on the growth of Rohu, Labeo rohita. Asian Fisheries Science 10(2): 139-147.

24. Shang YC (1990) Aquaculture economics analysis: an introduction. World Aquaculture Society 2.

25. Duncan DB (1955) Multiple range and multiple F testes. Biometrics11: 1-42.

26. Zar JH (1984) Biostatistics. Prentice-Hall, Inc. Englewood Cliffs, New Jersey, USA, pp: 718. 
27. SAS Institute (1988) SAS/STATTM Users Guide. RElease 6.03 edn. SAS Institute, Cary, USA.

28. Boyd CE (1990) Water Quality in Ponds for Aquaculture. Burmingham Publishing, Burmingham, USA, pp. 482.

29. Cholik F, Hanafi A (1992) A review of the status of the mud crab (Scylla spp.) \$shery and culture in Indonesia. In: The Mud Crab (ed. by C.A. Angell), Bay of Bengal Programme. Brackishwater Culture GCP/RAS/118/MUL, pp: 13-28.

30. Escritor GL (1972) Observations on the culture of the mud crab Scylla serrata. Coastal Aquaculture in the Indo Pacif Reg Fishing News (Books) Ltd, London, pp: 355-361.

31. Trino AT, Rodriguez EM (2002) Pen culture of mud crab Scylla serrata in tidal flats reforested with mangrove trees. Aquaculture 211(1): 125-134.

32. Hill BJ, William MJ, Dutton P (1982) Distribution of Juvenile, sub-adult and adult Scylla serrta (Crustacea: Porttunidae) on tidal flats in Australia. Marine Biology 69(1): 117-120.

33. Chen TP (1976) Aquaculture practices in Taiwan. CABI CAB Direct: 123-128.
34. Johnson WE (1965) On mechanism of self-regulation of population abundance in Oncorhynchus nerka. Mitt Int Verein Theor Angew13(1): 66-87.

35. Houde ED (1975) Effect of stocking density and food density on survival, growth and yield of laboratory reared of sea Brea, Archosargus rhomboidales (L.) (Sparidae)*. J Fish Biol 7(1): 115-127.

36. Bensam P (1986) Culture experiment on the crab Scylla serrata (Forskal) at Turiconin during 19751977 to assess growth and production. Proceedings of The Symposium On Coastal Aquaculture 4: 11831189.

37. Mwaluma J (2002) Pen Culture of the Mud Crab Scylla Mangrove System, Kenya. Western Indian Ocean J Marine Science 1(2): 127-133.

38. Trino AT, Millamena OM, Keenan C (2001) Pod culture of Mud crab Scylla serrata (Forskal) fed formulated diet with or without vitamin and mineral supplements. Asian Fisheries Science 14: 191-200.

39. Baliao DD, De Los Santos MA, Franco NM (1999) Pen culture of mudcrab in mangroves. SEAFDEC/AQD Institutional Repository 29: 10.

40. Boyd CE (1982) Water Quality Management for Pond Fish Culture. CAB Direct: 318. 